\title{
ERUPTIVE XANTHOMA: A MARKER OF HYPERTRIGLYCERIDEMIA
}

\author{
BIR HIPERTRIGLISERIDEMI BULGUSU: ERÜPTIF KSANTOM
}

\author{
Ramazan ÇAKMAK' (D), Özge TELCi ÇAKLILI² (D), Özlem SOYLUK SELÇUKBiRiCiK² (1) \\ 'Istanbul Basaksehir City Hospital, Department of Endocrinology and Metabolism, Istanbul, Turkey \\ ${ }^{2}$ Istanbul University, Istanbul Faculty of Medicine, Department of Endocrinology and Metabolism, Istanbul, Turkey
}

ORCID IDs of the authors: R.Ç. 0000-0003-3815-7444; Ö.T.Ç. 0000-0001-7566-5427; Ö.S.S. 0000-0003-0732-4764

Cite this article as: Cakmak R, Telci Caklili O, Soyluk Selcukbiricik O. Eruptive xanthoma: a marker of hypertriglyceridemia. J Ist Faculty Med 2021;84(4):603-6. doi: 10.26650/IUITFD.2021.844088

\section{ABSTRACT}

Eruptive xanthomas are benign lesions which are found in extensor surfaces of the extremities and are often associated with hypertriglyceridemia and/or uncontrolled diabetes. In this case report, we present a patient with hypertriglyceridemia, type 2 diabetes mellitus and eruptive xanthomas who recovers fully after treatment. A 37-year-old male patient presented to our clinic with reddish yellow lesions on his elbows. His body mass index was $30 \mathrm{~kg} / \mathrm{m}^{2}$ and his laboratory results showed high serum triglyceride and glucose levels (triglyceride $6548 \mathrm{mg} / \mathrm{dL}$, glucose $245 \mathrm{mg} / \mathrm{dL}$ ), his hemoglobin A1c was 11.2\%. Although eruptive xanthomas have a benign nature, they are associated with disease which often need lifelong treatment.

Keywords: Eruptive xanthoma, hypertriglyceridemia, type 2 diabetes

\section{ÖZET}

Erüptif ksantomlar, ekstremitelerin ekstansör yüzlerinde bulunan ve sıklıkla hipertrigliseridemi ve/veya kontrolsüz diyabet ile ilişkili iyi huylu lezyonlardır. Bu olgu sunumunda hipertrigliseridemi, tip 2 diyabet ve erüptif ksantomları olan ve tedaviden sonra tamamen iyileşen bir hastayı sunuyoruz. 37 yaşında erkek hasta, dirseklerinde kırmızımsı sarı renkli lezyonlar ile kliniğimize başvurdu. Vücut kitle indeksi $30 \mathrm{~kg} / \mathrm{m}^{2}$ ve laboratuvar sonuçlarında yüksek trigliserid ve glukoz seviyeleri (trigliserid $6548 \mathrm{mg} / \mathrm{dL}$, glukoz $245 \mathrm{mg} / \mathrm{dL}$ ) ile birlikte hemoglobin A1c \% 11,2 idi. Erüptif ksantomlar iyi huylu olmalarına rağmen, genellikle ömür boyu tedavi gerektiren hastalıklarla ilişkilidirler.

Anahtar Kelimeler: Erüptif ksantom, hipertrigliseridemi, tip 2 diyabet

\section{INTRODUCTION}

Eruptive xanthomas are benign lesions which are often associated with hypertriglyceridemia and/or uncontrolled diabetes (1). They can be the first symptom of a metabolic disorder or they can accompany an already deteriorating condition (2). It is seen with an estimated prevalence of 18 cases in 100000 inhabitants and it is pathognomonic for patients with triglyceride levels $>992 \mathrm{mg} / \mathrm{dL}$ ( $11.2 \mathrm{mmol} / \mathrm{L}$ ) (3). Lesions are usually found in extensor surfaces of the extremities or buttocks in some patients (4). In most cases lesions disappear after treatment of underlying metabolic condition. In this case report we present a patient with hypertriglyceridemia, type 2 diabetes and eruptive xanthomas who recovers fully after treatment.

\section{CASE PRESENTATION}

A 37-year-old male patient presented to our clinic with reddish yellow lesions on his elbows (Figure 1). He described them to be pruritic and present for more than a month. He described no fever or joint pain. He denied abdominal pain, visual changes, recent changes in medications, or contact with anyone with similar symptoms. He had no history of smoking, alcohol or drug use. Family history revealed type 2 diabetes mellitus in second degree relatives and there was no history of hypertriglyceridemia in the patient's family. Patient complained of polyuria, polydipsia and weight loss of 18 kilograms in the last 3 months. His body mass index was $30 \mathrm{~kg} / \mathrm{m}^{2}$ and waist circumference was $103.5 \mathrm{~cm}$. His vital signs were in normal

Corresponding author/iletişim kurulacak yazar: rmznckmk@yahoo.com

Submitted/Başvuru: 22.12.2020 • Revision Requested/Revizyon Talebi: 09.03.2021 •

Last Revision Received/Son Revizyon: 20.07.2021 • Accepted/Kabul: 30.07.2021 • Published Online/Online Yayın: 21.09 .2021 
range. There were multiple $2-5 \mathrm{~mm}$ sized eruptive xanthomas on both elbows and there was a palmar xanthoma on fourth finger of right hand along with the skinfold line (Figure 2). Punch biopsy revealed keratinized multilayered squamous epithelium and underneath it there were foamy macrophages below dermis compatible with eruptive xanthoma (Figure 3). Laboratory results showed high triglyceride and glucose levels (triglyceride $6548 \mathrm{mg} /$ $\mathrm{dL}$, total cholesterol $842 \mathrm{mg} / \mathrm{dL}$, LDL-cholesterol $261 \mathrm{mg} /$ $\mathrm{dL}$, HDL-cholesterol $38 \mathrm{mg} / \mathrm{dL}$, glucose $245 \mathrm{mg} / \mathrm{dL}$ ), his hemoglobin A1c was $11.2 \%$. Other than these parameters his laboratory work up was normal (Table 1). Patient was started on hypocaloric diet, metformin 2x1000 mg, insulin glargine $1 \times 14$ units, fenofibrate $267 \mathrm{mg} 1 \times 1$ and omega-3 2.5 grams/day. After one month his triglyceride levels resumed to normal values and his xanthomas faded. The patient provided informed consent for publication.

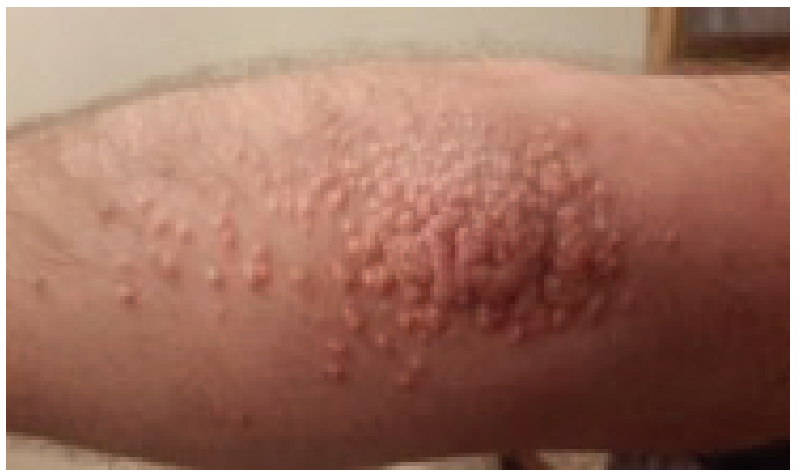

Figure 1: Eruptive xanthoma

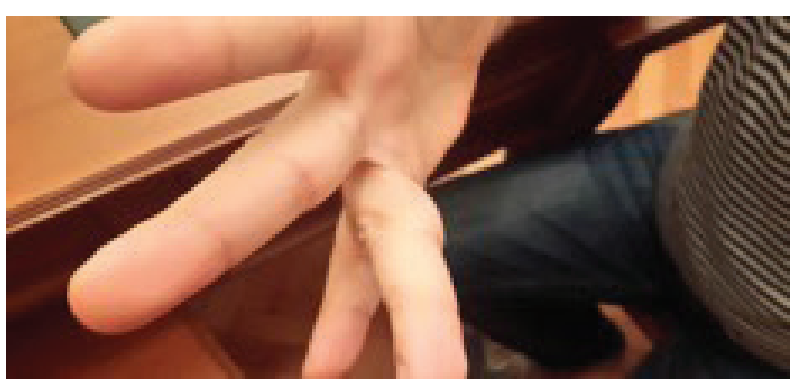

Figure 2: Palmar xanthoma

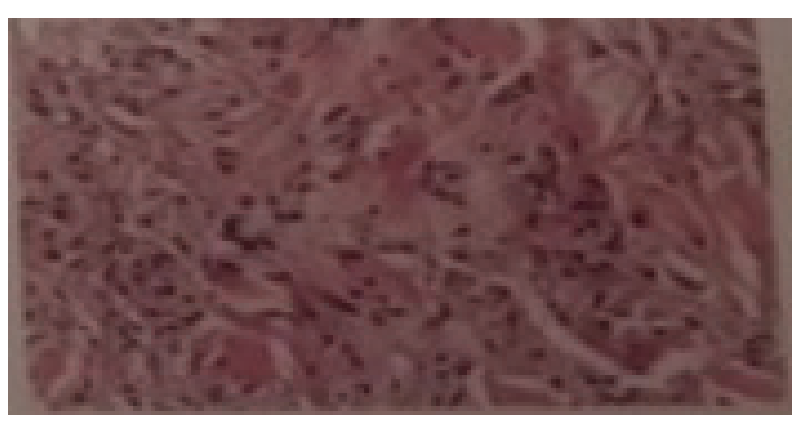

Figure 3: Pathology image
Table 1: Laboratory findings

\begin{tabular}{lcc}
\hline Laboratory parameters & Results & $\begin{array}{c}\text { Reference } \\
\text { values }\end{array}$ \\
\hline Fasting Blood Glucose (mg/dL) & 245 & $70-100$ \\
Hba1c $(\%)$ & 11.8 & $4.5-5.7$ \\
Fasting Insulin ( $\mu \mathrm{lU} / \mathrm{mL})$ & 16.6 & $0-25$ \\
Total cholesterol (mg/dL) & 842 & $0-200$ \\
Triglyceride (mg/dL) & 6548 & $0-150$ \\
HDL-cholesterol (mg/dL) & 38 & $40-60$ \\
LDL-cholesterol (mg/dL) & 261 & $0-100$ \\
Creatinine (mg/dL) & 0.9 & $0.7-1.2$ \\
Uric acid (mg/dL) & 5 & $2.4-5.7$ \\
Sodium (mEq/L) & 138 & $135-145$ \\
Potassium (mEq/L) & 4.16 & $3.5-5.3$ \\
Amilase (U/L) & 42 & $28-110$ \\
Lipase (U/L) & 37 & $13-60$ \\
Aspartate aminotransferase (U/L) & 22 & $10-35$ \\
Alanine aminotransferase (U/L) & 35 & $0-35$ \\
Gamma glutamyl transferase $(\mathrm{U} / \mathrm{L})$ & 51 & $15-85$ \\
Alkaline Phosphatase $(\mathrm{U} / \mathrm{L})$ & 84 & $30-105$ \\
Thyroid-stimulating hormone $(\mu \mathrm{U} / \mathrm{mL})$ & 1.6 & $0.27-4.2$ \\
Free thyroxine $(\mathrm{ng} / \mathrm{dL})$ & 1.12 & $0.93-1.7$ \\
\hline
\end{tabular}

\section{DISCUSSION}

There are five types of xanthomas; eruptive xanthomas, tuberous/tendinous xanthoma, flat xanthomas, verrucous xanthomas, and xanthelasma (5). Eruptive xanthomas are skin lesions which are a manifestation of hypertriglyceridemia and with keratinized multilayered squamous epithelium and foamy macrophages under the dermis in their pathology. Differential diagnosis of eruptive xanthomas includes Langerhans cell histiocytosis, disseminated granuloma annulare, nonLangerhans cell histiocytosis (xanthoma disseminatum, the micronodular form of juvenile xanthogranuloma), and generalized eruptive histiocytoma.

On the other hand, tendon xanthomas are closely associated with familial hypercholesterolemia and coronary heart disease (6). Xanthelasma are small, soft and yellowish lesions on the eyelids and are often bilateral. They can present in case of hyperlipidemia however in some cases there are no lipid disorders (7). Nevertheless Christoffersen et al. has reported an association between xanthelasma and coronary heart disease independent of conventional cardiac risk factors (8). 
Detection of eruptive xanthomas should lead to an early investigation of triglyceride, glucose, thyroid stimulating hormone and creatinine levels because they can be the telltale lesion of diabetes, hypothyroidism or chronic kidney disease. Because hypertriglyceridemia is associated with acute pancreatitis in some cases these lesions can help physicians diagnose the precise cause of abdominal pain in emergency units (9). Our patient did not have a secondary disease that could be the underlying cause of hyperlipidemia other than type 2 diabetes mellitus. He didn't have a family history of hyperlipidemia. Patient had high triglyceride and low HDL cholesterol levels. Although it seemed his lipid profile was compatible with type 1 hyperlipidemia of Frederickson classification because he also had high LDL levels, it was hard to distinguish from type 4 and type 5 hyperlipoproteinemia (10). His VLDL level couldn't be calculated due to high triglyceride levels and unlike his LDL, his VLDL was not measured directly. However, because he also had type 2 diabetes in an early age, it is plausible to think an early atherosclerotic disease associated with type 4 or type 5 hyperlipoproteinemia can also be present in this patient. Type 2 diabetes and high LDL are known atherosclerotic risk factors whereas the impact of hypertriglyceridemia on coronary heart disease has not been laid as clear as other classic risk factors. Lee et al. has suggested Apo B/ A1 ratio to identify cardiovascular risk more definitely in a patient with type 1 diabetes and hypertriglyceridemia (7). To the best of our knowledge, unlike tendon xanthomas, there are no reports of an association between eruptive xanthomas and cardiovascular disease to this date.

Studies have shown deleterious effects of non-esterified (free) fatty acids (NEFAs) on beta cell function (11). They induce nitric oxide mediated apoptosis and cause loss of beta cell function (12). Therefore, hyperlipidemia should be avoided in these patients and they should be ordered a strict diet to preserve beta cell function and to decrease fat deposit in visceral organs. Treatment of hyperlipidemia starts with diet and physical activity. Pharmacological treatment is added often in moderate and severe cases of hypertriglyceridemia. These treatments include fenofibrates, omega-3 fatty acids, niacin, insulin in patients with diabetes and triglyceride apheresis or plasmapheresis in patients with severe hypertriglyceridemia $(13,14)$. Volanesorsen is a new drug developed by antisense technology with promising results in patients with familial chylomicronemia syndrome (15).

\section{CONCLUSION}

In conclusion, although eruptive xanthomas have a benign nature, they are associated with disease s which often need lifelong treatment. Therefore, every physician should be aware of the appearance and disease burden of eruptive xanthomas.
Informed Consent: Written consent was obtained from the participants.

Peer Review: Externally peer-reviewed.

Author Contributions: Conception/Design of Study- R.Ç., Ö.T.Ç.; Data Acquisition- R.Ç.; Data Analysis/InterpretationÖ.S.S.; Drafting Manuscript- R.Ç., Ö.T.Ç.; Critical Revision of Manuscript- Ö.S.S.; Approval and Accountability- R.Ç., Ö.T.Ç., Ö.S.S.

Conflict of Interest: Authors declared no conflict of interest.

Financial Disclosure: Authors declared no financial support.

Bilgilendirilmiş Onam: Katılımcılardan bilgilendirilmiş onam alınmıştır.

\section{Hakem Değerlendirmesi: Dış bağımsız.}

Yazar Katkıları: Çalışma Konsepti/Tasarım- R.Ç., Ö.T.Ç.; Veri Toplama- R.Ç.; Veri Analizi/Yorumlama- Ö.S.S; Yazı Taslağı- R.Ç., Ö.T.Ç.; İçeriğin Eleştirel İncelemesi- Ö.S.S.; Son Onay ve Sorumluluk- R.Ç., Ö.T.Ç., Ö.S.S.

Çıkar Çatışması: Yazarlar çıkar çatışması beyan etmemişlerdir.

Finansal Destek: Yazarlar finansal destek beyan etmemişlerdir.

\section{REFERENCES}

1. Hsueh YC, Chou CL, Lee TI. Diabetic dyslipidemia with eruptive xanthoma. Cleve Clin J Med 2019;86(9):575. [CrossRef]

2. Kashif M, Kumar H, Misbahuddin K. An unusual presentation of eruptive xanthoma A case report and literature review. Medicine (Baltimore) 2016;95(37):e4866. [CrossRef]

3. Zak A, Zeman M, Slaby A, Vecka M. Xanthomas: clinical and pathophysiological relations. Biomed Pap Med Fac Univ Palacky Olomouc Czech Repub 2014;158(2):181-8. [CrossRef]

4. Kala J, Mostow EN. Eruptive xanthoma. N Engl J Med 2012;366(9):835. [CrossRef]

5. Streit E, Helmbold P. 65-year-old man with yellow-orange papules on both forearms. Eruptive xanthomas. Hautarzt 2009;60(10):834-7. [CrossRef]

6. Mangili LC, Miname MH, Silva PRS, Bittencourt MS, Rocha VZ, Mangili OC, et al. Achilles tendon xanthomas are associated withthe presence and burden of subclinical coronary atherosclerosis inheterozygous familial hypercholesterolemia: A pilot study. Atherosclerosis 2017;263:393-7. [CrossRef]

7. Lee SY, Sheth CA. Eruptive xanthoma associated with severe hypertriglyceridemia and poorly controlled type 1 diabetes mellitus. J Community Hosp Intern Med Perspect 2019;9(4):344-6. [CrossRef]

8. Christoffersen M, Frikke-Schmidt R, Schnohr P, Jensen GB, Nordestgaard BG, Tybjærg-Hansen A. Xanthelasmata, arcus corneae, and ischaemic vascular disease and death in general population: prospective cohort study. BMJ 2011;343:d5497. [CrossRef] 
9. Duzayak S, Sayiner ZA, Erkılıç S, Inaloz HS. Acute pancreatitis with eruptive xanthoma. BMJ Case Reports 2017;2017:bcr2017221543. [CrossRef]

10. Fredrickson DS. An international classification of hyperlipidemias and hyperlipoproteinemias. Ann Intern Med 1971;75(3):471-2. [CrossRef]

11. Cnop M. Fatty acids and glucolipotoxicity in the pathogenesis of Type 2 diabetes. Biochem Soc Trans 2008;36(Pt 3):348-52. [CrossRef]

12. Shimabukuro $M$, Ohneda $M$, Lee $Y$. Unger, RH. Role of nitric oxide in obesity induced $\beta$-cell disease. J Clin Invest 1997;100(2):290-5. [CrossRef]
13. Alagözlü H, Cindoruk M, Karakan T, Ünal S. Heparin and insulin in the treatment of hypertriglyceridemia-induced severe acute pancreatitis. Dig Dis Sci 2006;51(5):931-3. [CrossRef]

14. Ewald N, Kloer HU. Treatment options for severe hypertriglyceridemia (SHTG): the role of apheresis. Clin Res Cardiol Suppl 2012;7(Suppl 1):31-5. [CrossRef]

15. Witztum JL, Gaudet D, Freedman SD, Alexander VJ, Digenio A, Williams KR, et al. Volanesorsen and triglyceride levels in familial chylomicronemia syndrome. N Engl J Med 2019;381(6):531-42. [CrossRef] 